\title{
ORANG TUA MULTI ETNIK DI KOTA TANJUNG BALAI: GAYA PENGASUHAN DAN PERKEMBANGAN SOSIAL EMOSIONAL ANAK USIA DINI
}

\author{
MHD. HABIBU RAHMAN \\ Universitas Islam Negeri Sunan Kalijaga Yogyakarta \\ Email: habiburahman393@gmail.com
}

AULIA RAHMA

Institut Agama Islam An Nur Lampung

Email: auliarahma@an-nur.ac.id

Article received: 5 April 2020 Review process: 21 Mei 2020 Article Accepted: 5 Agustus 2020

Article published: 30 September 2020

\begin{abstract}
This research presents the parenting styles adopted by multi-ethnic parents of Asahan and Batak Toba ethnic groups. The culture brought by parents will affect parenting styles and will have an impact on aspects of child development, including the child's social emotional. This study aims to determine the types of parenting carried out by multi-ethnic parents, and to determine the factors that affect the social emotional development of children with multiethnic care. . The research method used in this research is descriptive qualitative with a psychological approach. Data analysis techniques include reducing data, presenting, drawing conclusions and verifying data. The results showed that the multi-ethnic parenting style in the city of Tanjung Balai based on seven parents resulted in different parenting styles, this was due to different educational and economic backgrounds. There was no problem with the multi-ethnic parenting style, some parents adopted a parenting style in accordance with the character of the two tribes, resulting in a new parenting style. The parenting styles produced by multi-ethnic parents can be grouped into two, namely permissive and authoritative parenting styles, where the permissive parenting style is applied by 3 parents, while the authoritative parenting style is applied by 4 parents. Regarding the effect of parenting style on the social emotional development of children, the permissive parenting style applied by parents with two different cultures tends to create children who are socially free and emotionally spoiled. Meanwhile, authoritative parenting applied by multi-ethnic parents tends to make children socially controlled, and emotionally proportional.
\end{abstract}

Keywords: Parenting style, Multi Ethnic, Emotional Social early childhood

\begin{abstract}
Abstrak
Penelitian ini menyajikan tentang gaya pengasuhan yang diterapkan oleh orangtua multi etnik yang bersuku melayu Asahan dan Batak Toba. Kebudayaan yang dibawa oleh orangtuaakan mempengaruhi gaya pengasuhan dan akan berdampak pada aspek perkembangan anak,
\end{abstract}


termasuk sosial emosional anak.Penelitian ini bertujuan untuk mengetahui jenis pengasuhan yang dilakukan orangtua multi etnik, dan mengetahui faktor-faktor yang mempengaruhi perkembangan sosial emosional anak dengan pengasuhan multi etnik. Metode penelitian yang digunakan dalam penelitian ini adalah deskriptif kualitatif dengan pendekatan psikologis. Teknik analisis data meliputi mereduksi data, menyajikan, menarik kesimpulan dan memverifikasi data. Hasil penelitian menggambarkan bahwa Gaya pengasuhan orang tua multi etnik di kota Tanjung Balai berdasarkan tujuh orang tua mengahasilkan gaya pengasuhan yang berbeda-beda, hal ini dikarenakan latar belakang pendidikan dan juga ekonomi yang berbeda. Tidak ditemukan adanya problema mengenai gaya pengasuhan orang tua yang multi etnik, beberapa orang tua menerapkan gaya asuh sesuai dengan karakter kedua suku sehingga menghasilkan suatu gaya asuh yang baru. Adapun gaya pengasuhan yang dihasilkan dari orang tua multi etnik ini dapat dikelompokan menjadi dua yaitu gaya pengasuhan permisif dan Autoritatif, dimana gaya pengasuhan permisif diterapkan oleh 3 orangtua, sedangkan gaya pengasuhan Autoritatif diterapkan oleh 4 orangtua. mengenai pengaruh gaya pngasuhan oragtua terhadap perkembangan sosial emosional anak gaya pengasuhan permisif yang diterapkan orang tua dengan dua kebudayaan yang berbeda cenderung menciptakan anak yang bebas secara sosial, dan manja secara emosional. Sedangkan pengasuhan autoritatif yang diterapkan orang tua multi etnik cenderung menjadikan anak terkontrol dalam sosial, dan proporsional secara emosional.

Kata Kunci: Gaya Pengasuhan, Multi Etnik, Sosial Emosional Anak Usia Dini

\section{PENDAHULUAN}

Keluarga adalah bagian terkecil dalam ruang lingkup masyarakat yang terdiri dari ayah, ibu, dan anak yang saling membutuhkan satu sama lain.Keluarga merupakan institusi yang sangat berperan dalam rangka melakukan sosialisasi, bahkan internalisasi, nilai-nilai pendidikan.Walaupun jumlah institusi pendidikan formal dari tingkat dasar sampai ke jenjang yang paling tinggi semakin hari semakin banyak, namun peran keluarga dalam transformasi nilai edukatif ini tetap tidak tergantikan.keluarga merupakan tempat pertumbuhan anak yang pertama di mana dia mendapatkan pengaruh dari anggota-anggotanya pada masa yang amat penting dan paling kritis dalam pendidikan anak, yaitu tahun-tahun pertama dalam kehidupanya.(Maurice J. Elias, 2003) menyebutkan bahwa pola asuh orang tua dalam keluarga berpengaruh besar pada tingkat keberhasilan anak untuk mencapai kesuksesan atau juga kegagalan pada pergaulannya di lingkungan masyarakat.Keluarga sebagai kelompok masyarakat terkecil mempunyai peran dominan dalam pertumbuhan dan perkembangan individu, terutama orang tua yang merupakan pendidik dan pengasuh pertama bagi setiap anak. Orang tua memiliki tugas mulia yang mengawali transfer ilmu kepada anak dan menjadi 
AWLADY: Jurnal Pendidikan Anak

Homepage: www.syekhnurjati.ac.id/jurnal/index.php/awlady

Email : pgrasyekhnurjati@gmail.com

P-ISSN: 2541-4658

E-ISSN: 2528-7427
Vol. 6, No. 2, September 2020

fondasi awal bagi perkembangan dan kelangsungan hidup anak. (Maragustam, 2015) menyebutkan pengetahuan setiap anak terkait dengan baik-buruk, benar-salah diperoleh dari polesan pendidikan lingkungan keluarga. Setiap anak akan berpotensi menjadi baik apabila lingkungannya mengajarkan kebaikan. Setiap anak memiliki perkembangan yang berbedabeda.Perkembangan yang dimiliki setiap anak harus senantiasa diberikan stimulus yang positif.

Aspek-aspek yang menjadi perhatian dalam internalisasi budaya pada proses pengasuhan diantaranya pembinaan nilai keagamaan, sopan santun, ketaatan kepada orang tua, disiplin dan tanggung jawab serta kemandirian.(Muhammad Nur Abdul Hanif Suwaid, 2010:45) Dengan pengasuhan yang baik akan membawa dampak pada pendidikan yang baik, terutama pendidikan Islam. Secara garis besar dunia pendidikan Islam perlu mendapatkan sentuhan modernitas. Sentuhan modernitas ini dapat berpengaruh terhadap ideologis-normatif yang menuntut sistem pendidikan Islam dalam memperluas dan mempertajam wawasan anak didik serta adanya mobilisasi pendidikan yang menuntut sistem pendidikan dalam mempersiapkan, dan menghasilkan out put berintegritas dan menghasilkan kepemimpinan modernitas yang inovatif. Selain itu, (Azyumardi Azra, 2012) menyebutkan bahwa mobilisasi ekonomi, sosial, dan budaya juga menuntut sistem pendidikan yang unggul, mempunyai nilai dan mampu memelihara stabilitas warisan budaya yang kondusif bagi pembangunan nasional.

Pendidikan anak di era modern di satu sisi mampu memberikan kemudahan dan bahkan menjadi model pengasuhan baru, selain itu disisi yang lain tentu saja era modern memberikan tantangan tersendiri kepada setiap orang tua. Berbagai kemajuan teknologi memudahkan anak dalam mendapatkan informasi, bahkan informasi tersebut lebih cepat hadir di kehidupan anak dari pada sarapan paginya, bahkan lebih cepat diterima oleh akal anak daripada nasihat dari orang tuanya.(Radliya et al., 2017) Kebutuhan anak dapat diperoleh secara instan. Anak-anak sejak usia dini sudah mengenal berbagai kecanggihan teknologi. Oleh sebab itu, dengan segala bentuk kecanggihan teknologi, orang tua harus mampu berpartisipasi, dan berkreasi dengan teknologi tersebut, sehingga mampu memanfaatkan teknologi dengan sebaik-baiknya. Sejatinya pendidikan yang diberikan sejak dini memiliki tujuan agar anak mampu beradaptasi dengan sluruh lingkungan.(Maulidya Ulfah, 2018) 
AWLADY: Jurnal Pendidikan Anak

Homepage: www.syekhnurjati.ac.id/jurnal/index.php/awlady

Email : pgrasyekhnurjati@gmail.com

P-ISSN: 2541-4658

E-ISSN: 2528-7427
Vol. 6, No. 2, September 2020

Pada dasarnya gaya komunikasi antara orangtua dan anak-anak dapat sangat berbeda diantara berbagai budaya yang melekat terhadapnya. Kebudayaan yang dimiliki orang tua sangat berpengaruh pada gaya pengasuhan, dan konteks budaya masyarakat berpotensi dapat membantu untuk memprediksi gaya pengasuhan orang tua di lingkungan tersebut.(Nauli et al., 2019) Kebudayaan yang dianut suatu masyarakat merupakan pandangan hidup yang berbentuk perilaku, nilai, kepercayaan, dan simbol-simbol yang diterima tanpa sadar dan diwariskan melalui proses komunikasi dari satu generasi ke generasi lain.(Alo Liliweri, 2002:64)Dengan kata lain budaya adalah suatu kebiasaan yang dimiliki manusia sebagai bagian dari masyarakat. Latar belakang budaya yang dimiliki orang tua akan berpengaruh kepada gaya pengasuhan dan perilaku yang ditunjukkan anak. Secara turun temurun kebudayaan tersebut akan terus berlangsung bahkan ketika seorang anak menjadi orang tua. Budaya mampu menentukan pola perasaan dan perilaku sehari-hari yang membentuk kisaran yang luas pada perilaku pengasuhan, dari nilai umum yang diajarkan orang tua hingga aspek nyata dalam keseharian.(Jane Brooks, 2011:47)

Kebudayaan suatu masyarakat akan berpengaruh dengan gaya pengasuhan suatu masyarakat terhadap anaknya, penelitian yang dilakukan oleh (Li \& Xie, 2017) menyatakan bahwa dalam konteks perubahan ekonomi, politik, dan sosial yang cepat di Cina, gaya pengasuhan orang tua generasi baru masih menghargai gaya pengasuhan tradisional, namun ini bukanlah menjadi satu-satunya gaya pengasuhan yang mereka gunakan, mereka jarang memerintahkan atau menghukum anak-anak dengan cara yang otoriter, mereka biasanya lebih suka menggunakan pengasuhan yang resmi.

Gaya pengasuhan tradisional Tiongkok menekankan posisi superior orangtua, yang cenderung ketat dan melakukan banyak kontrol psikologis terhadap anak-anak mereka.Namun, penelitian ini menemukan bahwa skor dalam keempat dimensi pengasuhan otoritatif lebih tinggi daripada pengasuhan otoriter. Dengan kata lain, orang tua dalam sampel penelitian menunjukkan kehangatan dan keterlibatan dalam pengasuhan mereka dan jarang menolak dan menghukum anak-anak mereka. Hasil penelitian ini konsisten dengan beberapa studi empiris tentang pengasuhan anak-anak dan remaja Tionghoa kontemporer Cina tetapi tampaknya jauh dari deskripsi ibu harimau tentang pengasuhan orang Cina sendiri dan dari 
AWLADY: Jurnal Pendidikan Anak

Homepage: www.syekhnurjati.ac.id/jurnal/index.php/awlady

Email : pgrasyekhnurjati@gmail.com

P-ISSN: 2541-4658

E-ISSN: 2528-7427

gaya pengasuhan tradisional Cina. Perbedaan-perbedaan ini menyoroti bagaimana gaya pengasuhan berubah seiring waktu.

Senada dengan penelitian Xiaowei, penelitian dari (Adibsereshki et al., 2018) menyatakan bahwa terdapat hubungan yang signifikan antara gaya pengasuhan permisif dengan kebiasaan anak seperti kesepian, kerentanan, ketidakpercayaan, kecacatan, standar yang tak henti-hentinya, kontrol yang tidak memadai, dan kegagalan. Penelitian dari (Yip et al., 2019)menawarkan program Parenting positif 6A yang dapat mengubah sikap pengasuhan orang tua, mengurangi stres pengasuhan, dan meningkatkan kemanjuran diri dalam mengasuh anak. Namun, kepercayaan akan strategi mempermalukan anak dalam pengasuhan masih umum bagi kalangan orang tua di Tiongkok Hongkong, yang mungkin mencerminkan bahwa orang tua di Tionghoa Hongkong masih sangat dipengaruhi oleh budaya kolektif tradisional yang berfokus pada penanaman kepekaan sosial. Diyakini bahwa Program Parenting Positif 6A memberikan keseimbangan antara strategi berbasis bukti dan akuntabilitas terhadap tradisi budaya Tiongkok.

Berkaitan dengan pengasuhan orangtua, Penelitian (Hart et al., 2019)telah menunjukkan bahwa mayoritas ibu Amerika Afrika cenderung terlibat dalam pengasuhan yang lebih makmur bergantung pada pengasuhan yang otoritatif, memperlihatkan keseimbangan kehangatan dan kontrol dari orangtua dengan perubahan perkembangan anak.Hasil penelitian (Ihmeideh \& Shawareb, 2014)menemukan bahwa gaya pengasuhan kepada anak memainkan peran penting dalam memperluas atau membatasi paparan anak-anak ke Internet. Telah ditemukan bahwa (1) gaya pengasuhan Internet otoritatif adalah gaya pengasuhan yang paling umum dipraktikkan oleh orang tua Yordania, diikuti oleh gaya pengasuhan yang permisif dan otoriter, dengan gaya pengasuhan yang lalai menjadi yang paling jarang digunakan; (2) anak-anak lebih cenderung menggunakan hiburan dan kegiatan rekreasi online daripada pendidikan, informasi, atau alat komunikasi; dan (3) gaya pengasuhan yang otoritatif merupakan prediktor signifikan penggunaan Internet oleh anakanak.

Adapun teori yang digunakan berkaitan dengan pengasuhan merujuk dari pendapat Baumrind dalam (Spera, 2005) mengidentifikasi tiga tipologi utama dalam pola pengasuhan anak, yaitu: autoritatif, otoriter dan permisif. Orangtua yang autoritatif menurut Baumrind 
AWLADY: Jurnal Pendidikan Anak

Homepage: www.syekhnurjati.ac.id/jurnal/index.php/awlady

Email : pgrasyekhnurjati@gmail.com

P-ISSN: 2541-4658

E-ISSN: 2528-7427
Vol. 6, No. 2, September 2020

adalah orang tua yang hangat dan responsif, menyediakan afeksi dan dukungan kepada anaknya.Orangtua yang otoriter tidak memberikan kehangatan dan tidak responsif terhadap anak-anaknya. Biasanya ciri orangtua otoriter antara lain: ketat atau keras, mengharapkan kepatuhan serta mengutamakan kekuatan/kekuasaan ketika anak-anak mereka berperilaku buruk. Selain itu, orangtua yang permisif cenderung lalai atau abai terhadap tingkat kedewasaan anak-anak serta mempunyai toleransi ketika anak-anak mereka menunjukkan tingkah laku yang buruk.

Perkembangan sosial emosional merupakan salah satu aspek yang harus dikembangkan pada anak usia dini.Untuk menstimulasi perkembangan sosial emosional anak dapat dilakukan dengan kegiatan bermain. Kegiatan bermain dapat dilakukan dengan kegiatan bermain yang sederhana dari setiap kebudayaan.(Hewi, 2020:51)selain itu kegiatan bermain bagi anak selain mendatangkan kegembiraan dan interaksi dengan teman-teman sebayanya, juga merupakan proses belajar yang menyebabkan terjadinya perubahan yang lebih baik pada aspek-aspek perkembangan anak usia dini seperti social emosionalnya.(Filtri, 2017). Kegiatan bermain dapat diterapkan oleh orang tua yang menerapkan pola pengasuhan yang tepat.

Berdasarkan beberapa penelitian yang telah dikemukakan, peneliti juga membahas tentang gaya pengasuhan orang tua.Pada penelitian sebelumnya hanya dibahas mengenai superior orangtua dalam mengasuh, kemudian bagaimana kebudayaan mempengaruhi pengasuhan orangtua.Pada metodologi terdapat kesamaan, namun berbeda objek yang diteliti.Sedangkan pada penelitian ini, yang menjadi daya tarik adalah bagaimana perbedaan kebudayaan dalam satu rumah menjadi sebuah pengasuhan yang diterapkan kepada anak. Penelitian ini ditujukan pada orang tua yang menikah dengan dua kebudayaan yang berbeda antara suku Batak Toba dan Suku Melayu Asahan, dan bagaimana hasil dari pengasuhan yang diterapkan oleh dua kebudayaan berbeda terhadap perkembangan sosial emosional anakusia 5-6 tahun.

\section{METODOLOGI}

Penelitian ini dirancang untuk memahami bagaimana gaya pengasuhan orang tua multi etnik di Kota Tanjung Balai dalam mengembangkan sosial emosional anak. Metode penelitian yang digunakan dalam penelitian ini adalah deskriptif kualitatif dengan pendekatan psikologis yang dilakukan langsung kepada subjek yang diteliti, guna 
AWLADY: Jurnal Pendidikan Anak

Homepage: www.syekhnurjati.ac.id/jurnal/index.php/awlady

Email : pgrasyekhnurjati@gmail.com

P-ISSN: 2541-4658

E-ISSN: 2528-7427
Vol. 6, No. 2, September 2020

memperoleh semua data yang berkaitan dengan gaya pengasuhan dan perkembangan sosial emosional anak usia dini. Adapun proses analisis data meliputi mereduksi data, menyajikan, menarik kesimpulan, dan memverifikasi data. Sedangkan dalam uji keabsahan data penitian ini menggunkan teknik triangulasi.

Subjek penelitian ini berjumlah 7 orang tua yang menikah dengan suku yang berbeda yaitu suami yang bersuku batak toba dan isteri yang bersuku melayu asahan. Peneeitian ini dilkukan di kotatanjung balai.Adapun peneliti memilih Penentuan subjek dilakukan pada saat mulai memasuki lapangan dan selama penelitian berlangsung. Adapun objeknya yaitu anak dari 7 orang tua tersebut alasannya karena ingin melihat dampak dari gaya pengasuhan orang tua yang berbeda suku terhadap pekembangan sosial emosional anak. Adapun waktu penelitian ini dilakukan pada tanggal 22 oktober -12 Desember 2019. Peneliti berusaha mendekatkan diri ke dalam ranah konseptual obyek penelitian, dalam hal ini peneliti berusaha mengetahui arti peristiwa dalam kaitannya dengan objek penelitian dan situasi penelitian.

\section{HASIL DAN PEMBAHASAN}

Berdasarkan penelitian di kota Tanjung Balaiterdapat beberapa keluarga multi etnik dimana dalam hal ini, peneliti memfokukan pada 7 orang tua yang menikah dengan berbeda suku yaitu suami yang bersuku Batak Toba dan isteri yang bersuku Melayu Asahan. Dari hasil penelitian terungkap bahwa dari ketujuh orang tua multi etnik tersebut mengahasilkan gaya pengasuhan yang berbeda-beda, hal ini dikarenakan latar belakang pendidikan dan juga ekonomi yang berbeda. Hal ini menunjukan bahwa orang tua yang berbeda suku dapat menghasilkan beberapa gaya pengasuhan yang baru dan berbeda.

Terdapat beberapa gaya pengasuhan yang juga berpengaruh terhadap perkembangan sosial emosional anak. Salah satunya yaitu ditemukan beberapa orang tua multi etnik yang menggabungkan gaya asuh dari masing-masing budaya mereka. Gaya pengasuhan suku Batak Toba yang lebih cenderung keras dan dan lebih menkankan pada aturan-aturan dalam keluarga yang harus dipatuhi oleh anak yang dipadukan dengan gaya pengasuhan suku Melayu Asahan yang cenderung lembut, penuh kasih sayang dan terkesan memanjakan anak, sehingga bila dipadukan kedua gaya asuh tersebut bisa saling melengkapi satu sama lain. 
AWLADY: Jurnal Pendidikan Anak

Homepage: www.syekhnurjati.ac.id/jurnal/index.php/awlady

Email : pgrasyekhnurjati@gmail.com

P-ISSN: 2541-4658

E-ISSN: 2528-7427
Vol. 6, No. 2, September 2020

Adapun perpaduan dari keduanya ini menumbulkan satu gaya asuh yang baru dimana anak mendapatkan dua gaya pengasuhan sekaligus dari kedua orang tuanya.

Selain perpaduan antara dua gaya pengasuhan dari suku yang berbeda, berdasarkan hasil penelitian ada juga orang tua multi etnik yang saling mengalah dan dan lebih memilih untuk tidak menerapkan gaya pengasuhan dari budaya masing-masing, dimana dalam hal ini orang tua lebih memilih gaya pengasuhan dengan menyesuaikan perkembngan zaman dan juga menyesuaikan situasi dan kondisi serta perkembangan anak, hal ini mereka lakukan demi kebaikan anak-anak mereka.Perubahan Sosial, Budaya, dan Teknologi (Margaret Nelson: 2010) berdampak pada upaya orang tua dalam mengantisipasi dan melakukan pencegahan sejak awal (early prevention) terhadap proyeksi dampak-dampak yang akan timbul. Penggunaan media digital telah mempengaruhi tumbuh kembang anak, dan orang tua dalam pengasuhannya, bahkan melahirkan model pengasuhan transenden (Sun Sun Lim:2019), hadirnya media teknologi menjadi new style pengasuhan.Beberapa orang tua cendrung mengalami kekhawatiran terhadap penggunaan media yang berlebihan tersebut. Perasaan khawatir dan kecemasan orangtua (parental anxiety) akan masa depan anak-anaknya sebagai reaksi atas perubahan sosial, ekonomi, dan teknologi telah mendorong orangtua untuk mencurahkan seluruh energi intelektual dan emosional, untuk menemukan sebuah konsep pengasuhan yang tepat dan atau lembaga pendidikan yang dapat memberikan pengasuhan dan pendidikan yang terbaik bagi anak-anaknya (Maia Cucchiara: 2013).

Berdarkan hasil penelitian gaya pengasuhan orang tua yang multi etnik dapat dikelompokan kedalam dua pola asuh yaitu pola asuh permisif dan pola asuh autoritatif Pengasuhan permisif yang diterapkan orang tua dengan dua kebudayaan yang berbeda cenderung menciptakan anak yang bebas secara sosial, dan manja secara emosional. Sedangkan pengasuhan autoritatif yang diterapkan orang tua multi etnik cenderung menjadikan anak terkontrol dalam sosial, dan proporsional secara emosional menyesuaikan keadaan yang terjadi.

\section{Gaya Pengasuhan permisif}

Sebagaimana diketahui bahwa pola asuh permisif adalah orang tua yang memberikan kebebasan secara penuh kepada anak untuk mengambil keputusan dan melakukannya serta tidak pernah memberikan penjelasan atau pengarahan kepada anak. Berdasarkan penelitian 
AWLADY: Jurnal Pendidikan Anak

Homepage: www.syekhnurjati.ac.id/jurnal/index.php/awlady

Email : pgrasyekhnurjati@gmail.com

P-ISSN: 2541-4658

E-ISSN: 2528-7427
Vol. 6, No. 2, September 2020

ditemukan bahwa penerapan pola asuh permisif terlihat dari beberapa jawaban informan yang menikah beda suku. Informan yang bernama Rahmad Sitorus berusia 50 tahun bersuku Batak Toba, berprofesi sebagai pedangang dengan latar belakang pendiikan SMP yang menikahi Siska bersuku Melayu Asahan, ibu rumah tangga danbelatar belakang pendiikan SD mereka memiliki 3 orang anak, Rahmad Sitorus mengatakan kepada peneliti bahwa: "kami tidak memiliki masalah walaupun kami berbeda suku, kami slama ini saling bekerja sama daam membesarkan anaanak kami walaupun masih terdapat banyak kekurangan. Kami sebagai orang tua yang memiliki karakter berbeda, dalam mengasuh anak masih terbawa dengan budaya yang saya terima dari orang tua, saya cenderung keras dalam mendidik anak, namun istri saya cenderung lembut, dan memberikan kebebasan kepada anak.Kesibukan bekerja menyebabkan anak cenderung lebih akrab dengan ibunya, dan istri saya memberikan kebebasan kepada anak, sehingga tidak bisa mengawasi anak-anak sepenuhnya".

Dari pernyataan responden di atas, dapat dipahami bahwa orang tua yang berbeda suku dan kebudayaan dalam hal mendidik anak tetap menggunakan gaya pengasuhan sesuai dengan ciri khas budayanya masing-masing dimana ayah yang bersuku Batak Toba identik keras dan ibu yang bersuku Melayu Asahan identik dengan lembut, sehingga kedua gaya pengasuhan tersebut bisa dipadukan untuk saling melengkapi dan tentunya menjadi satu gaya pengasuhan yang baru, dimana dalam hal ini anak mendapatkan nilai-nilai kepimpinan dan kedisipinan dari ayahnya yang cenderung keras dan mendapatkan nlai-nilai kelembutan dan kasih sayang dari sang ibu.

Pernyataan senada juga dikemukakan oleh respoden yang lain yaitu Jalaluddin Sitorus berusia 40 tahun, bersuku Batak Toba, berprofesi sebagai Nelayan, latar belakang pendidikan SD dan istrinya Aminah berusia 36 tahun bersuku Melayu Asahan, berprofesi sebagai Nelayan, latar belakang pendidikn SMP menjelaskan kepada peneliti bahwa: "mengenai pendidikan anak kami menyerahkan saja dengan anak, dia hendak sekolah kami persilahkan, jika tidak mau sekolah juga kami biarkan, tidak bisa juga kita memaksa sekolah jika anak tidak mau sekolah. Selain itu berkaitan dengan saya dan suami yang berbeda suku sejauh ini tidak pernah ada masalah dan tidak berpengaruh terhadap perlakuan kami kepada anak-anak kami”. 
AWLADY: Jurnal Pendidikan Anak

Homepage: www.syekhnurjati.ac.id/jurnal/index.php/awlady

Email : pgrasyekhnurjati@gmail.com

P-ISSN: 2541-4658

E-ISSN: 2528-7427
Vol. 6, No. 2, September 2020

Pernyataan informan tersebut di atas menandakan bahwa pernikahan dua suku yang berbeda tidak berpengaruh dalam penerapan gaya pengasuhan. Dalam hal in orang tua memberikan kebebasan dan tidak memberikan aturan-aturan tertentu. Dalam hal ini dpat disimpulkan bahwa kedua orang tua tersebut menerapkan gaya pengasuhan permisif, hal ini sesuai dengan yang dikemukakan oleh (Lestari S, 2012) bahwa gaya pengasuhan keluarga permisif tidak memberikan struktur dan batasan-batasan yang tepat bagi anak-anak mereka. Pola asuh permisif merupakan bentuk pengasuhan dimana orang tua memberikan kebebasan sebanyak mungkin pada anak untuk mengatur dirinya.(Kurnia \& Suprapti, 2018)Anak tidak dituntut untuk bertanggung jawab dan tidak banyak dikontrol oleh orang tua.

Selanjutnya dikatakan bahwa pola asuh permisif memandang anak sebagai seorang pribadi dan mendorong mereka untuk tidak berdisiplin dan anak diperbolehkan untuk mengatur tingkah lakunya sendiri.Dengan pola asuh seperti ini anak mendapat kebebasan sebanyak mungkin dari keluarganya.Mereka cenderung tidak menegur atau memperingatkan anak apabila anak sedang dalam bahaya, dan sangat sedikit bimbingan yang diberikan oleh mereka. Sebagaimana yang dikatakan oleh informan yang lain bernama Faisal yang berlatar belakang pendiikan SMP dan berprofesi sebagai nelayan bahwa:saye sehari-hari melaut dan bini sayengoncek kelapo, make ndak bise menjage anak-anak, kami pogi pagi balek petang(saya sehari-hari pergi kelaut dan istri saya mengupas kelapa, jadi tidak terlalu bisa mengawasi anak-anak, kami pergi pagi pulang sore).

Pernyataan dari Faisal juga mengisyaratkan bahwa orangtua umumnya kurang memperhatikan terhadap pendidikan dan pengasuhananak-anaknya.Pelaksanaan pola asuh permisif yang bersikap mengalah, menuruti semua keinginan, dan melindungi secara berlebihan serta memberikan atau memenuhi semua keinginan anak memang bersifat hangat, dan bahkan disukai oleh anak.Selain itu gaya pengasuhan permisif memuat hubungan antara anak dan orangtua penuh dengan kasih sayang, tetapi membuat anak menjadi agresif, emosional, dan suka menurutkan kata hatinya. Tidak memperdulikan bagaimana keadaan orangtua. Secara lebih luas, gaya pengasuhan seperti ini membuat anak-anak tidak terkendali, tidak patuh, emosional dan tingkah laku agresif di luar lingkungan keluarga.

Pola asuh ini membuat anak menghabiskan waktu di luar rumah dengan teman. Seharusnya sebagai orangtua, kesibukan bekerja tidak menjadi penghalang hilangnya 
AWLADY: Jurnal Pendidikan Anak

Homepage: www.syekhnurjati.ac.id/jurnal/index.php/awlady

Email : pgrasyekhnurjati@gmail.com

P-ISSN: 2541-4658

E-ISSN: 2528-7427
Vol. 6, No. 2, September 2020

tanggung jawab mengasuh, orangtua harus tetap berinteraksi, berkomunikasi dengan anak.(Widiasari \& Pujiati, 2017) Orangtua permisif adalah orangtua yang kaku dan berfokus pada kebutuhan mereka sendiri. Untuk anak yang masih berada pada usia keemasan, tentu saja orang tua yang permisif akan menyebabkan perkembangan yang dimiliki anak akan terhambat.

Selain mewawancari para orangtua, saya juga mengadakan wawancara dengan salah seorang ustadz yang mengajar Taman Pendidikan Qur'an (TPQ) di Kota Tanjung Balai.yaitu Ahmad Fauzi mengatakan bahwa: "terhadap pendidikan anak para orang tua disini umumnya memberikan kebebasan kepada anak, jika anaknya mau sekolah ya disekolahkan, tetapi jika anaknya tidak mau sekolah orang tua juga tidak memaksa”. Ahmad Fauzi selanjutnya mengatakan "bahwa mata pencarian orang tua disini rata-rata sebagai nelayan, dan pengupas kelapa, Agak sulit memberikan bimbingan dan pengawasan kepada anak kalau seharian bekerja di luar rumah. Orang tua di sini biasanya memang tidak terlalu memperdulikan akan pendidikan dan pengasuhan anak, karena disibukkan oleh kegiatan mencari nafkah bagi keluarga, yang mereka pentingkan adalah bagaimana anak bisa makan.”

Berdasarkan keterangan tersebut, gaya pengasuhan yang diterapkan oleh orang tua akan membawa dampak kepada generasi emas. Seharusnya di usia dini, anak mendapatkan stimulus yang positif dan berkelanjutan, namun kenyataannya tidak di dapatkan oleh anak. Gaya pengasuhan seperti ini tidak ada stimulus, pengendalian dan pengontrolan kepada anak.Dalam hal ini anak berusaha belajar sendiri bagaimana harus berperilaku dalam lingkungan sosial.Mereka tidak terorganisasi dengan baik atau tidak efektif dalam menjalankan rumah tangga, lemah dalam mendisiplinkan dan mengajar anak-anak, hanya menuntut sedikit dewasa dan hanya memberi sedikit perhatian dalam melatih kemandirian dan kepercayaan diri.

\section{Gaya Pengasuhan Autoritatif}

Gaya pengasuhan di keluarga multi etnik di Kota Tanjung Balai yang selanjutnya adalah pengasuhan autoritatif.Hal ini dapat diketahui dari hasil wawancara dengan beberapa orang informan penelitian yang bersuku Melayu Asahan dan Batak Toba.Nauli Sitorus mengatakan bahwa "anak-anak saya harus cerdas, harus lebih hebat dari saya, maka sejak kecil saya dan istri selalu memperhatikan perkembangan pendidikan anak saya, walaupun 
AWLADY: Jurnal Pendidikan Anak

Homepage: www.syekhnurjati.ac.id/jurnal/index.php/awlady

Email : pgrasyekhnurjati@gmail.com

P-ISSN: 2541-4658

E-ISSN: 2528-7427
Vol. 6, No. 2, September 2020

saya bukan orang berpendidikan, namun anak saya harus berpendidikan dan berguna untuk masyarakat".Informan lainnya yaitu Marwan, beliau menyebutkan bahwa "pada dasarnya anak itu mengikut bagaimana orang tuanya, jadi kalau saya menginginkan anak saya memiliki keperibadian yang baik, maka kami sebagai orang tuanya juga harus bisa menunjukkan contoh yang baik". Lebih lanjut Marwan 46 tahun,latar belakang pendidikan S1 berprofesi sebagai guru menyebutkan bahwa

"walaupun saya berasal dari kebudayaan Batak yang identik keras, dan istri saya dari suku Melayu yang identik lembut, namun kami sebagai orangtua tidak boleh egois dan terlalu memaksakan pola asuh yang kami terima dari orangtua kami dulu,karena kami menyadari zamannya sudah brubah sehingga dalam hal gaya pengasuhan kami selalu mengedepankan dengan situasi kondisi dan perkembangaan anak kamidan lebih responsif dalam memperhatikan perkembangan anak yang masih berada pada usia keemasan".

Tidak jauh berbeda dengan pendapat di atas, informan lain yaitu Fauziah Sitorus yang bekerja sebagai guru PAUD mengatakan: "menurut saya walaupun saya bersuku Batak, namun dalam hal mengasuh saya tetap menerapkan kerasnya budaya Batak pada prinsip kehidupan, melainkan pada perkembangan anak tentu saja saya menyesuaikan dengan kondisi anak". Lebih lanjut Fauziah mengatakan bahwa "saya sebagai guru PAUD jangan sampai hanya bisa mendidik anak orang, namun perkembangan dan pendidikan anak saya sendiri juga akan saya perhatikan" Dari jawaban informan tersebut dapat diketahui bahwa sebagai orangtua dia berupaya untuk tidak meninggalkan budaya yang dimilikinya dan memadukannya dengan budaya pengasuhan yang tepat sesuai situasi perkembangan anak.

Orangtua seperti ini memiliki prinsip yang kuat terhadap budaya, bersikap rasional, selalu mendasari tindakannya pada pemikiran, dan tetap memperhatikan perkembangan anak.(Sumargi \& Kristi, 2017) Gaya pengasuhan seperti ini memungkinkan anak untuk bebas namun tetap bisa bertanggung jawab. Orangtua yang dikategorikan menggunakan gaya pengasuhan autoritatif adalah orangtua yang berusaha untuk memperhatikan perkembangan anak, dan mengarahkan anak agar mampu bertingkah laku secara rasional.

Orangtua memberikan penjelasan mengenai tuntutan dan disiplin yang ditetapkan, tetapi tetap menggunakan wewenangnya atau memberikan hukuman jika dianggap perlu.Orangtua memberlakukan serangkaian standar dan peraturan yang dilakukan secara sungguh-sungguh dan konsisten. Orangtua autoritatif memiliki kontrol yang tinggi disertai 
AWLADY: Jurnal Pendidikan Anak

Homepage: www.syekhnurjati.ac.id/jurnal/index.php/awlady

Email : pgrasyekhnurjati@gmail.com

P-ISSN: 2541-4658

E-ISSN: 2528-7427
Vol. 6, No. 2, September 2020

kehangatan yang tinggi kepada anak. Hal tersebut dilakukan sejatinya bukan bermaksud mengekang anak, namun justru membuat anak merasa terlindungi.(Rakhmawati, 2015)Pola pengasuhan harus memberikan rasa nyaman kepada anak.

Hasil pengamatan peneliti, pola pengasuhan yang digunakan oleh para orangtua sebagian besar dipengaruhi oleh dipengaruhi oleh pola asuh orangtua mereka sebelumnya. Adapun orang tua yang berkebudayaan Batak Toba cenderung keras dalam mendidik anak sedangkan orangtua yang berkebudayaan Melayu Asahan cenderung lembut dalam mendidik anak.perpaduan budaya yang dimiliki beberapa orangtua di Kota Tanjung Balai menimbulkan perpaduan pengasuhan atau yang disebut dengan akulturasi parenting. Selanjutnya gaya pengasuhan yang diterapkan orang tua multi etnik membawa dampak pada perkembangan sosial emosional anak. Pola pengasuhan yang diterapkan orangtua di Tanjung Balai bersifat relatif konsisten dari waktu ke waktu.Pola pengasuhan ini dapat dirasakan oleh anak, dari segi negatif maupun positif. Berbicara mengenai cara orangtua dalam mendidik anak, tentu saja tidak dapat terlepas dari pemahaman dan pandangan orangtua dalam mendidik. Cara-cara mereka dalam mendidik sangat menentukan corak kepribadian anak mereka.

Berdasarkan 7 keluarga selaku responden dalam penelitian ini, terdapat 3 orangtua yang gaya pengasuhannya adalah permisif dan 4 orangtua gaya pengasuhannya autoritatif. Kedua model pengasuhanyang diterapkan orangtua di kota Tanjung Balai ini masing-masing membawa nilai positif dan negatif dalam kehidupan anak, selain itu pengasuhan yang diterapkan mengantarkan kepada rasa senang dan nyaman kepada setiap anak. Rasa senang yang tertanam dalam diri anak akan mengantarkan kepada ketercapaian dalam perkembangan anak.Perkembangan anak tersebut merujuk pada tingginya keseimbangan antara kontrol prilaku dan kehangatan dari orangtua.(Nurul Utami et al., 2016)Berdasarkan gaya pengasuhan yang diterapkan orangtua tersebut mengindikasikan bahwa butuh adanya pengetahuan dalam mengasuh anak. Pengetahuan dibutuhkan agar seorang anak kedepannya mampu memahami nilai-nilai kehidupan seperti mandiri, mampu bertahan hidup dalam tantangan zaman.(Ahmad Yani, Ery Khaeriyah, 2017)

Hasil penelitian ini juga menunjukkan bahwa dari akulturasi parenting kebudayaan melayu Asahan dengan kebudayaan Batak Toba, terdapat beberapa faktor yang berpengaruh terhadap perkembangan sosial emosional anak adalah: 
AWLADY: Jurnal Pendidikan Anak

Homepage: www.syekhnurjati.ac.id/jurnal/index.php/awlady

Email : pgrasyekhnurjati@gmail.com

P-ISSN: 2541-4658

E-ISSN: 2528-7427
Vol. 6, No. 2, September 2020

\section{Sikap dan Temperamen Orang Tua}

Seorang anak yang diasuh dengan baik dalam keluarganya akan berkembang menjadi orang dewasa yang sehat jiwa dan raganya, mempunyai kepribadian yang kuat, tidak mudah putus asa serta tangguh dalam menghadapi tekanan hidup. Temperamen merupakan karakteristik bawaan yang menentukan sensitivitas individual pada berbagai pengalaman dan tanggung jawab pada pola interaksi sosial. Walaupun temperamen individual ditentukan saat lahir, faktor lingkungan memiliki peran penting untuk menentukan gaya tingkah laku dapat dimodifikasi. Temperamen orangtua sangat berpengaruh pada perkembangan anak.(Kusnadi \& Agustin, 2019) Berdasarkan data yang diperoleh dalam penelitian ini bahwa orangtua yang aktivitasnya sehari-hari bekerja, seperti menjadi nelayan, mengupas kelapa dan sebagainya ketika sudah lelah maka akan berdampak pada sikap orangtua,dan akan memicu temperamen dan pada akhirnya akan mempengaruhi pengasuhan negatif.

Pengasuhan negatif akan berdampak negatif, juga terkonfirmasi dari hasil riset National Institute of Child Health and Human Development Early Child care Net-work tahun 2005 sebagaimana yang dikutip Brooks melaporkan bahwa orang tua yang mengalami stress disebabkan faktor kemiskinan akan melahirkan pola asuh yang tidak peka, kurang menstimulasi, lebih depresi dalam menghadapi keadaan dan kualitas relasi antar keluarga yang buruk akan berdampak pada anak dimana kemampuan kognitif dan bahasanya cendrung rendah. Penilaian yang diberikan oleh lingkungan sosial merekapun cendrung negatif yakni sebagai anak yang agresif, tidak patuh, lebih khawatir dan memiliki kecemasan yang berlebihan.(Brooks, 2011)

Temperamen orangtua memengaruhi pola pengasuhan dan bagaimana mereka merespon setiap perkembangan dan tingkah laku anak. Sikap dan temperamen orangtua merupakan faktor penentu yang sangat mempengaruhi kualitas generasi yang akan datang. Sikap yang baik dari pengasuhan orangtua akan mewujudkan perkembangan kemampuan anak seperti disiplin mau bekerjasama dengan orang lain, bersikap toleran, menghargai pendapat dan gagasan orang lain, mau bertanggung jawab dan bersikap matang dalam kehidupan yang heterogen (etnis, ras, budaya dan agama).

\section{Tingkat Aktivitas Sosial}


AWLADY: Jurnal Pendidikan Anak

Homepage: www.syekhnurjati.ac.id/jurnal/index.php/awlady

Email : pgrasyekhnurjati@gmail.com

P-ISSN: 2541-4658

E-ISSN: 2528-7427
Vol. 6, No. 2, September 2020

Perkembangan sosial emosional anak sangat dipengaruhi tingkat aktivitas sosial. Perkembangan sosial perlu diterapkan sebagai pembentukan pribadi dalam masyarakat untuk memperoleh kemampuan berprilaku sesuai dengan norma dan nilai yang ada.(Istiqomah et al., 2016)Orangtua yang jarang bersosialisasi dan berinteraksi dengan anak, maka anak akan cenderung memiliki sifat pendiam. Sejatinya, orang tua dan keluarga merupakan kelompok sosial yang pertama kali akan diamati oleh anak.(Novita \& Budiman, 2015)

Tinggi atau rendahnya aktivitas sosial yang diterima oleh anak ditentukan oleh stimulus yang diberikan orangtua.Hal ini sesuai dengan hasil penelitian Utami (2018:40) yang menyebutkan bahwa keadaan lingkungan yang baik, damai, aman dan tentram akan memperlancar perkembangan sosial anak dan sebaliknya apabila lingkungan dan aktivitas sosial tidak tentram, tidak damai, tidak aman, makaanak akan mengalami gangguan dalam proses perkembangan sosial. Masalah perilaku sosial emosional menjadi penting untuk dioptimalkan sejakusia dini sebagai persiapan anak dalam menjalani kehidupan bermasyarakat.(Rizqiyani \& Asmodilasti, 2020)Agar perkembangan sosial dan emosional anak tetap optimal maka orangtua harus melakukan pemantauan, interaksi, dan intervensi nilai positif.

Aktivitas sosial yang dilakukan anak akan menciptakan kepekaan sosial dan emosional, orangtua bisa mengajak anak melakukan kegiatan sosial yang sederhana yang membawa dampak baik bagi kehidupan anak. Dalam penelitian ini, terdapat sebanyak 4 Orangtua yang menerapkan pengasuhan autoritatif lebih cenderung mengajak anak dalam kegiatan sosial. Pengawasan dan penerapan sejak dini akan menghantarkan kepada aktivitas yang positif dalam diri anak.

\section{Jumlah Anak}

Walaupun program keluarga berencana sudah lama dikenal oleh masyarakat Indonesia, termasuk oleh warga Tanjung Balai, namun sampai sekarang masih banyak ditemukan warga yang mempunyai anak lebih dari dua orang. Perhatian orangtua terhadap satu atau dua orang anak tentu sangat berbeda jika dibandingkan dengan keluarga yang mempunyai banyak anak.(Ayun, 2017)Begitu pula perhatiannya dalam hal pengasuhan, terlebih jika keluarga tersebut ekonominya pas-pasan.Urutan kelahiran anak dalam keluarga memang tidak memiliki korelasi dengan gaya pengasuhan yang diterapkan orangtua di rumah, 
AWLADY: Jurnal Pendidikan Anak

Homepage: www.syekhnurjati.ac.id/jurnal/index.php/awlady

Email : pgrasyekhnurjati@gmail.com

P-ISSN: 2541-4658

E-ISSN: 2528-7427
Vol. 6, No. 2, September 2020

tidak begitu terlihat hubungan antara anak yang lahirlebih awal dengan anak yang lahir belakangan dengan gaya pengasuhan, namun semakin banyak jumlah anak dalam keluarga, maka ada kecenderungan bahwa orang tua tidak begitu menerapkan pola pengasuhan secara maksimal pada anak.(Setyowati, 2017:98) Hal tersebut dapat dipicu karena perhatian dan waktunya terbagi antara anak yang satu dengan anak yang lainnya, dan perkembangan emosional anak yang seharusnya bisa diperhatikan dengan baik, namun harus terabaikan dengan banyaknya anak.

Berdasarkan hasil wawancara dan pengamatan secara mendalam, ditemukan bahwa orang tua multi etnik dengan suku Batak Toba dan suku Melayu Asahan memiliki kebudayaan yang berbeda dan kebudayaan tersebut mempengaruhi gaya pengasuhan setiap orangtua. Adapun gaya pengasuhan yang diterapkan oleh 7 orangtua dalam penelitian ini yaitu pengasuhan permisif, dan pengasuhan autoritatif. Dua gaya pengasuhan ini dipengaruhi oleh status pendidikan orangtua, sikap dan temperamen orang tua, tingkat aktivitas sosial budaya setempat, dan jumlah anak. dari pengasuhan permisif cenderung menjadikan anak bebas mengikuti kemauannya, ada keterbatasan sosial, dan hanya mendengarkan pendapatnya sendiri. Sedangkan pengasuhan autoritatif yang diterapkan orang tua cenderung menjadikan anak lebih proporsional, menghargai pendapat orang lain, memiliki kontrol sosial, dan mampu mengendalikan emosi sesuai situasi dan kondisi yang terjadi.

\section{SIMPULAN}

Gaya pengasuhan orang tua multi etnik di kota Tanjung Balai merupakan gaya pengasuhan orang tua yang terdiri dari suku Batak Toba dan suku Melayu Asahan. Dari ketujuh orang multi etnik tersebut mengahasilkan gaya pengasuhan yang berbeda-beda, hal ini dikarenakan latar belakang pendidikan dan juga ekonomi yang berbeda, sehinngga memiliki pengaruh yang berbeda-beda pula terhadap perkembangan sosial emosional anak. Berdasarkan penelitian tidak ditemukan adanya problema mengenai gaya pengasuhan orang tua yang multi etnik, dalam hal ini justru ada orang tua saling menerapkan gaya asuh sesuai dengan karakter kedua suku tersebut dan tidak ada salah satu suku yang mendominasi, sehingga menghasilkan suatu gaya asuh yang baru yaitu perpaduan antara gaya asuh suku Batak Toba yang cnderung keras dan gaya asuh suku Melayu Asahan yang cenderung lembut. 
Disisi lain ada orang tua yang justru menerapkan gaya asuh yang baru dan mengikuti perkembangan zaman dan menyesuaikan dengan kondisi anak.

Adapun gaya pengasuhan yang dihasilkan dari orang tua multi etnik ini dapat dikelompokan mmenjadi dua yaitu gaya pengasuhan permisif dan Autoritatif, dimana gaya pengasuhan permisif diterapkan oleh 3 orang tua, sedangkan gaya pengasuhan Autoritatif diterapkan oleh 4 orang tua. mengenai pengaruh gaya pngasuhan oragtua terhadap perkembangan sosial emosional anak gaya pengasuhan permisif yang diterapkan orang tua dengan dua kebudayaan yang berbeda cenderung menciptakan anak yang bebas secara sosial, dan manja secara emosional. Sedangkan pengasuhan autoritatif yang diterapkan orang tua multi etnik cenderung menjadikan anak terkontrol dalam sosial, dan proporsional secara emosional menyesuaikan keadaan yang terjadi. Adapun beberapa faktor yang mempengaruhi perkembangan sosial emosional anak dari segi pengasuhan orang tua di kota Tanjung Balai yaitu sikap dan temperamen orang tua, tingkat aktifitas sosial, dan jumlah anak.

\section{DAFTAR PUSTAKA}

Adibsereshki, N., Rafi, M. A., \& Aval, M. H. (2018). Looking into some of the risk factors of mental health: the mediating role of maladaptive schemas in mothers 'parenting style and child anxiety disorders. DOI: 10.1108/JPMH-08-2017-0028. pp. 125-147.

Ahmad Yani, Ery Khaeriyah, M. U. (2017). Implementasi Islamic Parenting Dalam Membentuk Karakter Anak Usia Dini Di Ra At-Taqwa Kota Cirebon. AWLADY : Jurnal Pendidikan Anak, 3(1), 153-174.

Alo Liliweri. (2002). Makna Budaya dalam Komunikasi antar Budaya. LkiS Pelangi Aksara.

Ayun, Q. (2017). Pola Asuh Orang Tua dan Metode Pengasuhan dalam Membentuk Kepribadian Anak. ThufuLA: Jurnal Inovasi Pendidikan Guru Raudhatul Athfal, 5(1), $102-121$.

Azyumardi Azra. (2012). Pendidikan Islam: Tradisi dan Modernisasi di Tegah Tantangan Millenium III. Kencana.

Filtri, H. (2017). Perkembangan emosional Anak Usia Dini Usia 5-6 Tahun Ditinjau Dari Ibu Yang Bekerja Title. PAUD Lectura: Jurnal Pendidkan Anak Usia Dini, 1(1), 32-37.

Hart, J. R., Coates, E. E., \& Bynum, M. A. S. (2019). Parenting Style and Parent-Adolescent Relationship Quality in African American Mother-Adolescent Dyads. May. DOI: 10.1080/15295192.2019.1642085. pp. 98-124.

Hewi, L. (2020). Penggunaan Permainan Dadu Literasi Untuk Perkembangan Sosial Emosional Di Tk Al-Aqsho Konawe Selatan. AWLADY: Jurnal Pendidikan Anak, Vol. 6, No.

Ihmeideh, F., \& Shawareb, A. (2014). Journal of Research in Childhood The Association Between Internet Parenting Styles and Children's Use of the Internet at Home. November 2018. DOI: 10.1080/02568543.2014.944723. pp. 114-135.

Istiqomah, N., Lathif, M. A., \& Khutobah, K. (2016). Peningkatan Perkembangan Sosial dan 
Emosional Melalui Kegiatan Outbound pada Anak Kelompok B di TK Asy-Syafa'ah Jember Tahun Pelajaran 2015/2016. Jurnal Edukasi, 3(2), 19-21.

Jane Brooks. (2011). The Process of Parenting (Rahmat Fajar (ed.)). Pustaka Pelajar.

Kurnia, S. D., \& Suprapti, A. (2018). Pola asuh orang tua pada anak yang berperilaku agresif. Ilmiah Potensia, 3(1), 1-6.

Kusnadi, S. K., \& Agustin, A. (2019). Parental Emotional Coaching untuk Meningkatkan Gaya Pengasuhan dan Penerimaan Orang Tua yang Memiliki Anak Tunarungu. Jurnal Psikologi Teori Dan Terapan, 9(2), 148-159.

Lestari S. (2012). Psikologi Keluarga: Penanaman Nilai dan Penanganan Koonflik dalam Keluarga. Kencana.

Li, X., \& Xie, J. (2017). Parenting styles of Chinese families and children's social-emotional and cognitive developmental outcomes. 18(July). DOI: 10.1080/1350293X.2017.1331077. pp. 75-98.

Maragustam. (2015). Filsafat Pendidikan Islam: Menuju Pembentukan Karakter Mengahadapi Arus Global. Kurnia Kalam Semesta.

Maulidya Ulfah. (2018). Peningkatan Kemampuan Sosial Anak Usia Dini Melalui Permainan Gelas Bocor. Al-Fitrah: Journal of Early Childhood Islamic Education, 2(1), 242-250.

Maurice J. Elias, S. E. T. \& B. S. F. (2003). Cara-cara Efektif Mengasuh Anak dengan EQ: Mengapa Penting Membina Disiplin Diri, Tanggung Jawab dan Kesehatan Emosional Anak-anak pada Masa Kini (M. J. Fuad (ed.)). Kaifa.

Muhammad Nur Abdul Hanif Suwaid. (2010). Propetic Parenting: Cara Nabi Mendidik Anak. Pro-U Media.

Nauli, V. A., Karnadi, K., \& Meilani, S. M. (2019). Peran Ibu Pedagang Pasar 24 Jam Terhadap Perkembangan Moral Anak (Penelitian Studi Kasus di Kota Bekasi). Jurnal Obsesi : Jurnal Pendidikan Anak Usia Dini, 3(1), 241-253.

Novita, D., \& Budiman, M. H. (2015). Pengaruh Pola Pengasuhan Orangtua Dan Proses Pembelajaran Di Sekolah Terhadap Tingkat Kreativitas Anak Prasekolah (4-5 Tahun). Jurnal Pendidikan, 16(2), 100-109.

Nurul Utami, A., Hernawati, N., \& Alfiasari, A. (2016). Pengasuhan Orang Tua Yang Seimbang Sebagai Kunci Penting Pembentukan Karakter Remaja. Jurnal Pendidikan Karakter, 1, 72-84.

Pendidikan, K., \& Kebudayaan, D. A. N. (2014). Menteri Pendidikan Dan Kebudayaan Republik Indonesia NOMOR 137 TAHUN 2014.

Radliya, N. R., Apriliya, S., \& Zakiyyah, T. R. (2017). Pengaruh Penggunaan Gawai Terhadap Perkembangan Sosial Emosional Anak Usia Dini. Jurnal Paud Agapedia, 1(1), $1-12$.

Rakhmawati, I. (2015). Peran Keluarga dalam Pengasuhan Anak. Jurnalbimbingan Konseling Isla, 6(1), 1-18.

Rizqiyani, R., \& Asmodilasti, A. (2020). Perilaku Prososial Anak Taman Kanak-Kanak Dilihat Dari Pendidik Anak Usia Dini. AWLADY: Jurnal Pendidikan Anak, 6(1), 110123.

Spera, C. (2005). A Review of the Relationship Among Parenting Practices, Parenting Styles , and Adolescent School Achievement. 17(2), DOI: 10.1007/s10648-005-3950-1. pp. 125-146.

Sulastri, S., \& Ahmad Tarmizi, A. T. (2017). Peran Orang Tua Dalam Pendidikan Anak Usia 
Dini. Raudhatul Athfal: Jurnal Pendidikan Islam Anak Usia Dini, 1(1), 61-80.

Sumargi, A. M., \& Kristi, A. N. (2017). Well-Being Orang Tua, Pengasuhan Otoritatif, dan Perilaku Bermasalah pada Remaja. Jurnal Psikologi, 44(3), 185-194.

Widiasari, Y., \& Pujiati, D. (2017). Pengasuhan Anak Usia Dini Bagi Orang Tua Pekerja. JURNAL INDRIA (Jurnal Ilmiah Pendidikan Prasekolah Dan Sekolah Awal), 2(2), 6877.

Yip, F. W. L., Zelman, D., \& Low, A. (2019). How to improve parenting in Hong Kong by training : the 6As Positive Parenting Program. 22(1), DOI: 10.1108/PAP-04-2019-0003. 